\title{
My Role as a Clinical Supervisor
}

Jennifer Forth

They say that teaching is not a job but a vocation, so it was with some trepidation that I agreed to have a KU MTEFL student shadow me in the fall semester in the hopes of eventually teaching my 032 class. Isaac had studied German as an undergrad and fallen in love with a Japanese woman while studying abroad. In the hopes of getting a job teaching in Japan, he started the MTEFL program. Unfortunately, because he was not in the K-12 track, he had found himself in his final semester and had no teaching experience due to no practicum being arranged for him. Enter the good people of the AEC.

Marcellino asked me if I would consider taking on Isaac for the semester. He told me his background and I decided it might be fun even though it was my first time teaching the class also. After a few emails and adding him to our Blackboard site, Isaac was in my classroom, helping out with monitoring small group discussions and examining the textbook. In class I found it was also helpful to have another explanation into meanings for vocabulary and their usage from someone who was from a different part of the country than me and of a different generation. It gave the class a chance to see that various usages exist and that sometimes one pronunciation is more common than another depending on where that person was from originally or what their specialization may have been. For example, the word data has two perfectly acceptable pronunciations, but one is more indicative of a study of the sciences (or a love of Star Trek The Next Generation) than the other.

After a few weeks in, we had opportunity to sit down and listen to the audio recordings of the class' first presentation. Isaac confessed that he had taken an assessment class already as part of his coursework and he did a very good job in analyzing the main issues each student had to address to improve. It also allowed us a chance to discuss how a language that is more familiar to us, like Japanese, may seem easier to understand and we may be more forgiving of their mistakes. A few weeks later, I gave him the week’s listening logs to correct. This was an opportunity to enter grades into Blackboard as well as to record responses to their Voiceboard summaries and mimicked sentences. It was also a reminder to Isaac that teaching is more than just showing up and performing the textbook to the audience. He completed each of these with gusto.

Eventually the time came for a teaching demonstration to be arranged. I admit I was a little nervous because I had now had a chance to talk to some of my colleagues and had heard the most horrendous stories about their experiences with student teachers. Some were downright shocking! But I also figured that by this point the class was comfortable with Isaac's presence and many had already met him as a conversation partner so it posed no difficulties. His KU supervisor was, of course, only available on days when the class was not offered, but eventually a date late in November was arranged and I prepared the class for this experience by teaching the idiom “to get one's feet wet”. Isaac added to the discussion by saying he would like, in his final semester, at the very least to see the beach. I gave him several opportunities to jump in and teach a section of the unit we were covering as a way to monitor his work and give tips as needed before the big day arrived. I wanted to see what he could do without loads of preparation time first.

His actual teaching day arrived and I introduced myself to the young woman (his KU supervisor?) who sat in the back of our room and typed away on her laptop. I was struck by the difference between her lack of interaction with the class or him and the teaching observations I have had by fellow AEC staff. I confess I was also struck by the thoroughness of Isaac's lesson plan in terms of stated learning goals and content standards and his expectations of the students by the end of the hour. He was terribly enthusiastic and loved to use positive reinforcement, especially on the more reticent members of the class. I was not surprised that he had planned too much and allowed him to continue into the second hour even though the observer had left. I also pointed out to him a tendency to call upon the Japanese students more often than the others and his need to write more on the board for an intermediate class. He was good at giving alternative examples when they came up in discussion and I feel this will get stronger with experience. 
One day late in the term I had gotten caught out in a meeting and arrived to class a few minutes late. This is very uncharacteristic of me and I felt awful. But, I am also a twenty-two year veteran of these trenches so I tried to think of a way to cover for my delay. As I walked into class, Isaac was at the front of the room talking to the class about what we had studied the day before and asking them to turn to the next section in their books. During the break I told him I had purposely come in late to see if he would take the initiative and get the class started. He was thrilled that I trusted him so and that he had "passed" my little test. Kids.

All in all, I would say the experience was highly successful for Isaac, myself and for my class. I think hearing someone else's voice once in a while is a good thing for everyone. I was reminded of my early days of teaching and the advice that was given and the advice I wish someone had given me as well. It has also reminded me of the need for things like writing on the board more often than we sometimes do when caught up in the moment and made me grateful for my years of experience to facilitate the classroom management needed to pull this all off. Isaac is now applying for jobs in Japan and promises to keep me updated on his adventures. Another teacher is born. 